\title{
Nutrition Value, Feed Efficiency and Species of Seagrass as a Feed of Wild Dugong (Dugong dugon) in Lingayan island, Tolitoli, Central Sulawesi
}

\author{
Ardiansyah Nurdin $^{1^{*}}$, Agik Suprayogi ${ }^{2}$, Aryani S. Satyaningtijas ${ }^{2}$, Huda S. Darusman ${ }^{2,3}$ \\ 1Postgraduate Student, Department of Anatomy, Physiology and Pharmacology, Bogor Agricultural \\ University, Jl. Agatis, Kampus IPB Darmaga Bogor 16680, Indonesia \\ ${ }^{2}$ Department of of Anatomy, Physiology and Pharmacology, Bogor Agricultural University, Jl. Agatis, \\ Kampus IPB Darmaga Bogor 16680, Indonesia \\ ${ }^{3}$ Primate Research Center, Bogor Agricultural University
}

*Corresponding author: Ardiansyah Nurdin (e-mail: ardiansyahnurdin96@gmail.com)

\begin{abstract}
Dugong are endangered herbivorous marine mammals, which one of the causes of extinction is degradation of seagrass as main feed of the dugong to survive. Aim of this study was to measure the quality of seagrass of wild dugong in Lingayan island, Central Sulawesi. The results showed proximat analysis value of Halophyla sp. Halodule $s p$ and Cymodocea sp as seagrass species respectively showed values crude protein of $6.86 \%, 7.69 \%$ and $8.79 \%$, crude fiber of $10.77 \%, 18.36 \%$ and $24.26 \%$, crude fat of $0.99 \%, 1.81$ and $1.5 \%$, calcium of $0.79 \%, 2.12 \%$ and $1.89 \%$, phosphorus of $0.34 \%, 0.34 \%$ and 0.26 and gross energy of $163.4 \mathrm{cal} / \mathrm{kg}, 300.5 \mathrm{cal} / \mathrm{kg}$ and $319.5 \mathrm{cal} / \mathrm{kg}$. Cymodocea sp is the best feed for dugong because it contains high energy of $319.5 \mathrm{cal} / \mathrm{kg}$ and high protein $8.79 \%$, if compared with Halophyla sp of $1622 \mathrm{cal} / \mathrm{kg}$ ) and Halodule sp of $3014 \mathrm{cal} / \mathrm{kg}$ ) furthermore (ymodocea sp has a fairly high crude fat content of $1.44 \%$ which will increase fat levels under the skin (subcutaneous) dugong as insulators of changing environmental conditions. Nutrient content contained in Cymodocea sp found in Lingayan Island is worthy of being the main feed for dugong.
\end{abstract}

Key words: Dugong, nutrition value, proximat, Lingayan island, seagrass

Copyright @ $2019 \mathrm{JRVI}$. All rights reserved.

\section{Introduction}

Indonesia, well-known as one of the countries the greatest country which has a great biodiversity potential in the world. One type of marine mammal found in Indonesian island, namely dugongs or dugong (Dugong dugon), which almost found in all Indonesian island (Marsh et al. 1982). The spread of dugong populations in Indonesia includes northern Irian Jaya, North, South, and Central Sulawesi, Sumatra, East Timor, West Maluku, Southeast Java, the south coast of East Java and the southern coast of Kalimantan (Allen et al. 1976).

Dugong dugon is in the sirenia order and dugong genus, is a marine mammal classified into endangered animals by The World Conservation Union (Nishiwaki et al. 1979). In 1970 the dugong population in Indonesia reached 10,000, but in 1994 the population was only 1,000 (Marsh et al. 2003). Dugong has been classified as a 'Vulnerable' category according to IUCN 
2006. This mammal has a very unique nature because it is classified as a beach grass (seagrass) eater. Dugongs usually live on the Indo-Pacific ocean coast. Dugongs are also commonly referred to as sea cows (Nair and Mohan 1977).

Dugong population has declined since dugong has a reproductive capacity of $5 \%$ per year (Iskandar et al. 2006). Dugong breeding is very slow and only gives birth to a child in each pregnancy so that the development of the population will be slow too. The number of dugong populations is increasingly diminishing due to hunting and habitat damage (Anderson 1981). Other contributing factors are human activity on the coast and infectious disease events (Campbell and Ladds 1979).

Dugong use seagrass as a main feed and doing habitat for foraging with the seagrass (Preen 1993). Decline of seagrass population will certainly affect the life and livelihood of dugongs, especially in the supply of feed. Dugong's main feed is seagrass which according to research results more than $90 \%$ of the stomach contents of the dugong consist of seagrasses. The rest are some types of algae (seaweed) (Marsh 1982).

Tolitoli Regency is one area that has seagrass habitat that is still healthy and abundant. The abundance of seagrasses in the area can be a very good habitat for the dugong's living location and also become a conservation area for the dugong in the future.

Dugong rescue efforts covering information on the health aspects of dugong have not been widely carried out because some researchers still focus on observing biological aspects, habitat evaluation, as well as searching methods for calculating populations in the high seas (Sheppard et al. 2007). This research will be conducted to identify the value of seagrass nutrition contained in Tolitoli Regency as a superior feed for dugong as indicators of health assessment of dugongs that live wild.

\section{Materials and Methods}

This study used 1 dugong which was found during the study time. Dugong is maintained for 14 days for the stabilization process and adaptation to the new environment with an average sea water temperature of $32 \pm 0.83^{\circ} \mathrm{C}$ and an average temperature of $30 \pm 0.15^{\circ} \mathrm{C}$. Animals are kept in a conventional cage in a circle with a diameter of $10 \mathrm{~m}$ and a depth of 2-5 $\mathrm{m}$ which is designed by considering aspects of animal welfare. Dugong is given seagrass food that has been identified and then analyzed to see its nutritional value in the area around the study site

The sampling technique using wild dugong in Lingayan island. Seagrass was identified by the quadratic transect method using a $100 \mathrm{~m}$ transect rope. The rope is drawn perpendicular to the coastline and a square of $0.5 \times 0.5 \mathrm{~m}$ is placed on every $3 \mathrm{~m}$ of the transect. The distance between the substations in the study area is $50 \mathrm{~m}$ based on McKenzie and Yoshida (2009).

Dugong was restrained and left it to eat in the seagrass beds which were identified after the dugong feeding track was observed. Selection of feeding trail is done by selecting the longest trail. Seagrasses around the selected trail will be collected at 3 points randomly using $1 \times 1 \mathrm{~m} 2$ transect and then weighed wet weight and averaged and calculated the area of seagrass, average observation station (RSP), consumption per 4.5 hours shows the speed of feeding which can describe the level eating preferences (palatability) (Roslinda and Afdal 2005).

Seagrasses with the highest level of palatability were analysis by proximate analysis to measure its nutritional value. Proximate analysis is a chemical test to find out nutrient content of a feed or feed raw material. Proximate analysis method first developed by Henneberg and Stohman 
in 1860 on a research laboratory in Weende, Germany (Hartadi et al. 1997). McDonald et al. (1995) explained that the proximate analysis was divided into six nutrient fractions namely water content, ash, crude protein, crude fat, crude fiber and extract material without nitrogen (BETN).

Feed efficiency analysis used dugong's faecal samples and seagrass species which were used as feed sources for dugong. After 24 hours of feeding, feces are taken at the bottom of the cage and put into a plastic sample, labeled and then weighed in the wet weight. Specifically, we can see the type of seagrass consumed by dugong from the condition of feces. The collected faeces are then taken and examined for the remainder of seagrass (roots, stems, and remaining leaves) that are not completely digested in the dugong digestive tract. The collection of seagrass samples given as dugong feed and collecting dugong feces was carried out for 3 days of observation. Stool samples in each observation day were taken 20-30 g, then homogenized. The collection of seagrass samples given as dugong feed and the collection of dugong feces was analyzed the levels of proximate (water, ash, fat, protein and crude fiber), minerals (calcium and phosphorus), and gross energy (Giri 2013).

The data obtained in the species of seagrass and proximate analysis data of feed efficiency will be presented in table and then analyzed descriptively by displaying the species of seagrass and proximate analysis data and value of feed efficiency of wild dugong.

\section{Results and Discussions}

\section{Identification of Seagrass}

The results showed in Table 1 that there were 9 types of seagrass in the research location. In Table 1 it can be seen that the highest level of palatability is the type of seagrass Cymodocea $s p$ with palatability value reached $(++++)$, followed by Halodule $s p$ with palatability reached $(+++)$ and Halophila sp with $(++)$, whereas Enhalus acroides and Thalasia hemprichii types are two types of seagrass that are not consumed at all by dugongs indicated by the absence of traces of feeding tracks that appear. Therefore, dugongs as herbivorous animals will depend on the distribution of seagrasses. Seagrass beds are the main food source habitat for dugongs in search of primary feed in the form of seagrasses (Marsh et al. 1977; Lanyon et al. 2002; Preen 1993). Damage to seagrass habitats will have an impact on the life cycle of the dugong in terms of providing food sources.

Table 1. Identification of seagrass species and level of palatability

\begin{tabular}{cccc}
\hline NO & Seagrass Species & Species Percentage & Palatability Level \\
\hline 1 & Enhalus acroides & 100 & - \\
2 & Thalasia hemprichii & 100 & - \\
3 & Syringodium isoetifolium & 100 & - \\
4 & Cymodocea rotundata & 80 & ++++ \\
5 & Cymodocea serrulata & 20 & ++ \\
6 & Halophila ovalis & 70 & + \\
7 & Halophila minor & 30 & +++ \\
8 & Halodule uninervis & 70 & \\
9 & Halodule Pinnifolia & 30 & \\
\hline
\end{tabular}

Description : $(-)$ indicated no trace of feeding track ; $(+)$ showed $\pm 1 \mathrm{~m}^{2}$ feeding track area; $(++)$ showed $\pm 2 \mathrm{~m}^{2}$ feeding track area; $(+++)$ showed $\pm 3 \mathrm{~m}^{2}$ feeding track area; $(++++)$ showed $\pm 4 \mathrm{~m}^{2}$ feeding track area

Analysis of feed at the location of study showed that dugong select their feed based on the level of palatability to certain seagrass species. Dugong's feeding behavior is to do grazing or feeding by pulling out the seagrass up to the roots, so that the dugong feeding's track will be clearly 
visible. Dugong trail feeding length varies depending on the age of the dugong and seagrass type density. Dugong's that consume seagrasses with short morphological structures such as Halodule and Halophila, will see their feeding grooves with a width of $19-26 \mathrm{~cm}$ and a length of $8 \mathrm{~m}$ (Anderson and Birtles 1978). The dugong were observed which can spend as much as $12199.2 \mathrm{~g}$ of wet seagrass every day (Wake 1975). Giri (2013) stated that the dugong had greedy eating habits, where adults could consume $25-30 \mathrm{~kg}$ of wet seagrass every day.

\section{Seagrass Nutrition Value}

Nutritional analysis of three seagrass species showed that $C y$ modocea $s p$ had a higher protein and gross energy content than Halophila $s p$ and Halodule sp (Table 2). Cymodocea $s p$ is a good feed for dugong because dugong consume seagrass that contains high energy and nitrogen (De Longh et al. 2007). Cymodocea sp also had crude fat (1.44\%) and BETN (34.84\%) higher descriptively than Halophila $s p(0.98 \%$ and $22.90 \%)$. The fat of dugong, especially under the skin (subcutaneous) functions as an insulator of heat and cold (Linder 1992), while BETN is a source of carbohydrates (Marlina and Askar 2004; Anggorodi 1979).

Tabel 2. Seagrass nutrition value

\begin{tabular}{cccc}
\hline Composition & \multicolumn{3}{c}{ Seagrass Species } \\
\cline { 2 - 4 } (\%) & Halophila sp & Halodule sp & Cymodocea sp \\
\hline Dry Weight & $19.95 \pm 0.11$ & $25.11 \pm 0.14$ & $28.05 \pm 0.27$ \\
Crude protein & $6.86 \pm 0.1$ & $7.695 \pm 0.21$ & $8.79 \pm 0$ \\
Crude fat & $0.995 \pm 0.02$ & $1.81 \pm 0.28$ & $1.5 \pm 0.08$ \\
Crude fiber & $10.77 \pm 0.45$ & $18.365 \pm 1.05$ & $24.26 \pm 1.41$ \\
BETN & $22.705 \pm 0.8$ & $43.835 \pm 0.12$ & $35.98 \pm 1.61$ \\
Ash & $57.475 \pm 0.9$ & $29.37 \pm 0.1$ & $29.97 \pm 0.44$ \\
Calsium & $0.795 \pm 0.05$ & $2.12 \pm 0.14$ & $1.895 \pm 0.12$ \\
Phosphorus & $0.34 \pm 0$ & $0.345 \pm 0.02$ & $0.260 \pm 0$ \\
Gros energy & $163.4 \pm 1.7$ & $300.05 \pm 1.91$ & $319.5 \pm 3.54$ \\
(kal/kg) & & &
\end{tabular}

The digestive process in dugong's intestine, a high fiber concentration can help in holding the filtration rate of water as long as food passes in the intestinal tract, so the dugong will release feces with greater and softer consistency (Murray et al. 2003). When viewed from the phosphorus content of Halodule $s p$ has a higher content of $0.76 \%$ than Cymodocea $s p$ and Halophila sp (0.26\% and $0.33 \%)$. Phosphorus serves as a source of high-energy phosphate (especially ATP) which is needed to energize all bodily functions (Murray et al. 2003). Therefore, Halodule sp can be a supplement for dugong feed in meeting mineral needs. This is in line with research conducted by (Sheppard et al. 2010) which states that dugong consumes seagrass that contains high energy and nitrogen.

\section{Feed Efficiency}

The feed efficiency analysis of dugong feed are shown in Table 3, where dugong has a very good metabolism for the efficiency of Cymodocea $s p$. This is indicated by the percentage of feed efficiency more than $90 \%$. Research conducted on dugong using seagrass type Syringodium isoetifolium at Seaworld Indonesia (SWI) also showed the results of feed efficiency greater than 90\% (Giri 2013). These results explain that the digestibility of dugong feed in SWI would be better if given food found in its natural habitat. Mammalian bodies, including dugongs, need adequate amounts of nutrients to provide free energy (Goto et al, 2003).

In general, the results of research conducted at Sea World Indonesia (SWI) show different values compared to the results of the research conducted. This value difference may occur, because of 
the different types of seagrass consumed and the effect of seagrass habitat itself. Seagrass in this study had a percentage of crude fiber digestibility of $12.01 \%$, crude protein of $61.03 \%$, ash of $51.09 \%$, BETN of $57.03 \%$. and crude fat of $95.08 \%$, it shows that seagrass species Cymodecea $\mathrm{sp}$ is very well used as the main feed of dugong in the waters of Lingayan Island, Tolitoli Regency.

Tabel 3. Feed efficiency of Cymodocea $s p$ in wild dugong

\begin{tabular}{cc}
\hline Analysis Type (\%) & Efficiency (\%) \\
\hline Dry ingredients & 43.06 \\
Ash & 51.09 \\
Crude protein & 61.03 \\
Crude fiber & 12.01 \\
Crude fat & 95.08 \\
BETN & 57.03 \\
Calsium & 99.19 \\
Phosporus & 97.04 \\
\hline
\end{tabular}

Seagrass Zostera marina in Toba Aquarium captive research in Japan has a crude protein content (in dry weight) of $16.3 \%$ (Goto et al. 2008), while seagrass Cymodecea sp in this study has a crude protein content (in dry weight) of $19.07 \%$, It showed that the seagrass of Cymodecea $s p$ was very good to be used as a dugong feed in the waters of Lingayan Island, Tolitoli Regency.

\section{Conclusion}

Seagrass species found in Lingayan Island, Tolitoli, Central Sulawesi are Enhalus acoroides, Thalasia hemprichii, Cymodocea rotundata, Cymodocea serrulata, Halophila ovalis, Halophila minor, Halodule uninervis, Halodule pinnifolia, and Syringodium isoetifolium. The results of seagrass nutrition value analysis showed that Cymodocea $s p$ had the best nutritional and palatability values. The levels of nutrients in Cymodocea $s p$ which found in Lingayan island deserve highest nutritious feed of dugong.

\section{Acknowledgments}

The authors thanks to Postgraduate members, Department of Anatomy, Physiology and Pharmacology, Bogor Agricultural University for helping and facilitating the authors during this experiment. The authors state there is no conflict of interest with the parties concerned in this research.

\section{Refferences}

Allen, JF., Lepes, MM., Budiarso, IT., Sumitro, Dr., Hammond, D. 1976. Some observations on the biology of the dugong (Dugong dugon) from the waters of south Sulawesi. J Aquat. Mamm. 4 (1) : 33-48

Anderson, PK. 1981 The behaviour of Dugong (Dugong dugon) in relation to conservation and management. Wildlife Research, 22(1) : 14-21

Anderson, PK., Birtles, A. 1978. Behaviour and Ecology of the Dugong, Dugong Dugon (Sirenia): Observations in Shoalwater and Cleveland Bays, Queensland. Wildlife Research. 5(1) : 1-23

Anggorodi, R. 1979. Ilmu makanan ternak umum. PT. Gramedia, Jakarta. Hal: 273-277.

Campbell, RSF., Ladds, PW. 1979. Diseases of the Dugong in North-Eastern Autralia: A prelimenary report. Proceeding of a Seminar/Workshop held at James Cook University. Page 8-13 
Giri, SN. 2013. Quality and Efficiency of Dugong's (Dugong dugon) Feed and also Syringodium isoetifolium Seagrass Abundance at Northern Lamaran Island, Bojonegara Waters, Serang, Banten.

Goto, MA,. Watanabe, S,. Karita, N,. Tokita, Y,. Yamamoto, Y,. Wakaki, S,. Asano, Y,. Oka., Furuta. 2008. Nutrient and energy consumption of captive mature dugong (Dugong dugon) consuming eelgrass at the Toba Aquarium. J Marine and Freshwater Behaviour and Physiology. 41 (3): 169-177

Hartadi, H., Reksohadiprojo, AD., Tillman. 1997. Tabel Komposisi Pakan untuk Indonesia.

Iskandar, M., Sumitro., Sudranto, R., Hendrokusumo, S., Suprayogi A., Setijanto H., Darusman HS. 2006. Dugong in SeaWorld Indonesia. In. Proceeding of 1st International Asia Association Veterinary School (AAVS) Scientific Conference, July 2006, Jakarta, Indonesia

IUCN. 2006. IUCN Red List of Threatened Species. Gland, Switzerland, IUCN.

Lanyon, JM., Sneath, H L., Kirkwood, JM., Slade, RW. 2002. Establishing a mark-recapture program for dugongs in Moreton Bay, south-east Queensland. Australian Mammalogy. 24 (1) : 51-56

Lanyon, JM. 2003. Distribution and abundance of dugongs in Moreton Bay, Queensland, Australia. J Wildl Res. 30 (1) : 397-409

Linder, MC. 1992. Biokimia nutrisi dan metabolisme: Dengan pemakaian secara klinis. UIPress : Jakarta. Hal 781

Marlina, N., Askar, S. 2004. Komposisi kimia beberapa bahan limbah pertanian dan industri pengolahan hasil pertanian. Prosiding Temu Teknis Nasional Tenaga Fungsional Pertanian: Hal 99-103

Marsh, H. 2003. Aerial Surveys and the Potential Biological Removal Technique Indicate that the Torres Strait Dugong Fishery is Unsuistainable.

Marsh, H., Chanells, PW., Heinshon, GE., Morrisey, I. 1982. Analysis of Stomach Contents of Dugongs from Queensland. Aus. Wildl. Res. 9 (1) : 55-67

Marsh H. 1977. The alimentary canal of the Dugong. Australian Mam Soc Bull. 4 (32) : 3645

McDonald, PM., Edwards, RS., Greenhalg, JFD., Morgan, CA. 1995. Animal Nutrition. $5^{\text {th }}$ Edn. Addison Wesley Longman. Singapore Pte.Ltd

Murray, RK., Granner, DK., Mayes, PA., Rodwell, VW. 2003. Biokimia harper. Ed. ke-25. Penerbit Buku Kedokteran EGC, Jakarta. Hal 401-408.

Nair, RV., Mohan, RSL. 1977. Studies on the vocalisation the sea cow Dugong dugon in captivity. Indian J Fish. 22 (1) : 277-278

Nishiwaski, M., Kasuya, T., Tobayama, T., Miyazaki, N., Kataoka, T. 1979. Distribution of the Dugong in the word. In. Proceeding of a Seminar/Workshop held at James Cook University 8-13 May 1979

Preen, A. 1993. Dugong : cultivation grazers of sea grass (Abstrak). Sirenews. $20: 14-15$

Reddy, LM., Dierauf, LA., Gulland, FMD. 2001. Marine mammals as sentinels of ocean health (2nd ed.). San Diego: Academic Press. Page 285-290

Roslinda, SS., Afdal, M. 2005. Potensi kualitas daun cabe-cabe (Asystasia gangetica) dan markisa hutan (Passiflora foetida L.) sebagai hijauan makanan ternak kambing lokal. J. Ilmiah IImu-llmu Peternakan. 8(1): 47-55

Sheppard, JK, Jones, RE., Lawler, IR. 2010. Dugong habitat use in relation to seagrass nutrients, tides, and diel cycles. Marine Mammal Science 26 (4): 855-879.

Sheppard, JK., Lawler, IR., Marsh, H. 2007. Seagrass as pasture for seacows:Landscapelevel Dugong habitat evaluation. Estuarine, Costal and ShelfScience. 7 (1) : 117-132 